\title{
Chemical characteristics and health hazards of heavy metals in shallow groundwater: case study Anloga community, Volta Region, Ghana
}

\author{
Osei Akoto ${ }^{1}$ - Justice Agbeshie Teku ${ }^{1} \cdot$ Diane Gasinu $^{1}$
}

Received: 30 March 2017 / Accepted: 18 February 2019 / Published online: 5 March 2019

(c) The Author(s) 2019

\begin{abstract}
Five water samples each were collected from six shallow wells which serve as source of drinking water at different locations within the Anloga community of the Volta Region in Ghana. Samples were analyzed for physicochemical characteristics, and human health risk associated with the consumption of heavy metals in the samples was also assessed. The results showed that $\mathrm{pH}, \mathrm{EC}$, water hardness, fluoride and sulfate levels were below the maximum permissible levels recommended by the WHO for drinking but chloride and nitrate levels in well $\mathrm{A}_{6}$ were above their respective WHO limits. Concentration of heavy metals showed $\mathrm{Cd}$ and Pd toxicities in some of the wells since their concentrations were higher than the WHO accepted limit for drinking water. Estimated non-carcinogenic health risks of the metals through ingestion were less than 1 in some of the wells, indicating small to no health hazard; however, high non-carcinogenic risk was recorded in well 2, 3 and 5 indicating a potential health hazard to the local residents. Health risk through dermal injection of the metals was found to be less than 1 , indicating no health risk associated with water samples via dermal absorption. Cancer risk computed for $\mathrm{Cd}$ ranged from $1.82 \mathrm{E}-02$ in well $\mathrm{A}_{5}$ to $9.09 \mathrm{E}-02$ in well $\mathrm{A}_{1}$ and $\mathrm{A}_{6}$, indicating that consumption of water from these wells could result in an excess of 2-9 cancer cases per 100 people. The risk of developing cancer from $\mathrm{Pb}$ as a result of consuming water from wells $\mathrm{A}_{1}, \mathrm{~A}_{2}$ and $\mathrm{A}_{5}$ was estimated to be $3.69 \mathrm{E}-06$.
\end{abstract}

Keywords Cancer $\cdot$ Contaminated water $\cdot$ Exposure $\cdot$ Health risk

\section{Introduction}

The crucial role groundwater plays as a source of fresh water for humans well-being as well as many aquatic ecosystem, which cannot be underestimated. Groundwater represents over $90 \%$ of the world's readily available freshwater resource (Boswinkel 2000). According to some estimates, about 2 billion people depend upon groundwater for their drinking water supply (ISARM 2009; Puri and Aureli 2009). In Ghana, water from shallow groundwater wells serves as a source of drinking water for residences in most agricultural and rural areas. As a result, various groundwater development programs have established over 11,500 boreholes and

Osei Akoto

wofakmann@yahoo.com

1 Department of Chemistry, Kwame Nkrumah University of Science and Technology, Kumasi, Ghana
45,000 hand-dug wells countrywide (Gyau-Boakye and Dapaa-Siakwan 2000).

The quality of groundwater, particularly shallow groundwater, is changing as a result of human activities. This is because, contaminants in surface water, which replenishes groundwater systems can move through the soil and end up in the groundwater (Lapworth et al. 2012). Contamination problems are increasing because of improper disposal of the growing number of toxic substances that are used in industry and agriculture. It has also been reported that many household wells are contaminated by substances from sources such as septic systems, underground tanks, solid wastes from human and livestock (Zaporozec 1981). Even where no sources of anthropogenic contamination exist, there is the potential for natural levels of toxic metals and other chemicals in groundwater becoming harmful to human health (Prasanth et al. 2012). This has been highlighted in Bangladesh and some part of West Bengal in India where natural levels of arsenic in shallow groundwater have been 
found to produce harmful effects on humans (Shankar et al. 2014; Akoto and Adiyiah 2007: Anawara et al. 2002).

Drinking contaminated groundwater can have serious health effects. Diseases such as hepatitis and dysentery may be caused by contamination from septic tank waste. Poisoning may be caused by toxins that have leached into well water supplies. Among the wide range of contaminants that affect water quality, heavy metals are of particular concern due to their strong toxicity even at low concentrations and persistent nature (Marcovecchio et al. 2007). Heavy metals and metalloids can cause serious human health effects with varied symptoms depending on the nature and quantity of the metal ingested. Long-term ingestion of metals in drinking water may result in illnesses such as bladder, lung and skin cancers by As (Asante et al. 2007; de Miguel et al. 2007; Guo et al. 2007); neurotoxicity by $\mathrm{Hg}$ (Johnson and Atchison 2009) and disruption of the immune system by $\mathrm{Pb}$ (Mishra 2009). There is therefore the need to assess the chemical characteristics and evaluate the human health risks from metals in drinking water from shallow wells within the Anloga area. Such understanding will help strengthen water resource management and pollution control programs.

Anloga, with a population of about 36,000 , is located along the eastern coastline of the Republic of Ghana (Fig. 1). It is located on latitude $5.8^{0}$ North and longitude $0.9^{0}$ East, and it is $43 \mathrm{~m}$ elevation above sea level. Residents in this community are mainly farmers and have used agrochemicals including fertilizers in the cultivation and production of various cash crops such as maize, okro, pepper and cassava (Helstrup 2006). They rely mainly on groundwater from wells drilled into the shallow unconfined aquifer within the community for domestic and agricultural purposes without any treatment but are unaware of the possible hazards of using contaminated water and their associated adverse health effects. Unfortunately, the extent of heavy metal contamination and other water quality parameters in groundwater from

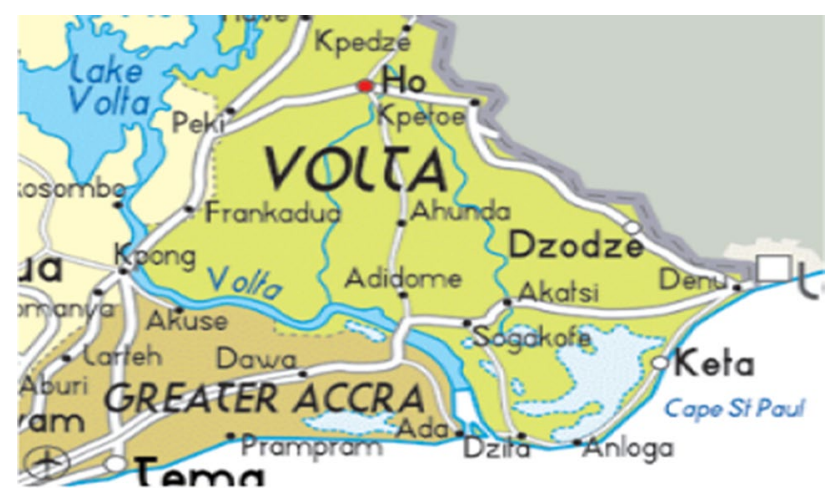

Fig. 1 Map of southeast part of Ghana showing the study area thus Anloga shallow wells in this area and risk they pose to consumers have not been studied.

Again the vulnerability of aquifers within the community to pollution from various sources does not deter the inhabitants as domestic waste discharge including sewage and soakaway are constructed without due regard to the fact that their discharge can pollute the aquifer system (UNEP 2003). This is particularly critical in areas that are heavily dependent on groundwater such as Anloga, where groundwater has been designated as the principal source of drinking water (Ponce 2006).

\section{Geology and hydrology of the Anloga area}

The hydrogeology of Anloga is mainly made up of Cenozoic and Mesozoic sediments which consist of sea (coast) sand, sandy clay gravel, marine shale, unconsolidated alluvial sediments, glauconitic sandstone and limestone(Gyau-Boakye and Dapaa-Siakwan 2000). Three different aquifers occur in these formations and are found to be a potential source of groundwater. These are the unconfined aquifers which occur in the sand very close to the sea (coast). Its depth is between 2 and $4 \mathrm{~m}$ and contains fresh meteoric water. The intermediate aquifers are either confined or semi-confined and occur in deposit of sandy clay and gravels with a depth of 6-120 m and contained saline water. The limestone aquifers contained fresh groundwater and have a depth of 120-300 m. The aquifers system recharge mainly by direct infiltration of precipitate through fracture and fault zones and also by weathering zone through the sandy (Kortatsi 1994).

Major objectives of the present study were: (1) to measure the concentrations of dissolved ions and some metals in shallow groundwater samples collected from six (6) wells use as drinking water by the citizens of Anlong, (2) to compare the measured levels of the ions and metals with national and international drinking water quality guidelines and, (3) to assess the health risks associated with selected of metals in the water samples.

\section{Materials and methods}

\section{Sampling}

Prior to sampling, all glassware and sampling bottles used were conditioned by washing with detergent and rinsed with distilled water. They were then soaked overnight with a dilute nitric acid solution and then rinsing three times with deionized water and dried in an oven. The polyethylene bottles were tightly covered and send to the sampling site. At the sampling site, the bottles were rinsed with sample water at the point of sampling to saturate the bottle with the sample water. Water samples were collected from six shallow 
groundwater wells located in unconfined aquifers distributed throughout the study area. The $\mathrm{pH}$ and electrical conductivity (EC) of the non-filtered samples were measured in situ using a calibrated $\mathrm{pH}$ and $\mathrm{EC}$ meter, respectively. For each sample, one part meant for metal analysis was acidified with $\mathrm{HNO}_{3}$ to $\mathrm{pH}<2$. The samples were labeled, stored in an ice chest with ice and finally transported to the laboratory for analysis. All the analyses were done by standard methods according to APHA, AWWA (1 992). Monthly, water samples were collected from each well for a period of five (5) months from November 2015 to March 2016.

\section{Digestion of samples for metal analysis}

Digestion of samples for metal analysis was done using concentrated $\mathrm{HNO}_{3}$ according to (Akoto et al. 2008). Concentrated $\mathrm{HNO}_{3}(5 \mathrm{~mL})$ was added to $50 \mathrm{~mL}$ of water sample in a $100 \mathrm{~mL}$ beaker. This was heated on a hot plate until its volume reduced to about $20 \mathrm{~mL}$. Another $5 \mathrm{~mL}$ of concentrated $\mathrm{HNO}_{3}$ was added and then heated for another $10 \mathrm{~min}$. The sample was allowed to cool to room temperature. About $5 \mathrm{~mL}$ of $\mathrm{HNO}_{3}$ was used to rinse the sides of the beaker, and the solution was quantitatively transferred into a $50-\mathrm{mL}$ volumetric flask and made up to the mark with distilled water. A blank solution was similarly prepared. Heavy metal analysis was done using atomic absorption spectrophotometer (Agilent 200 series AA) calibration curves were drawn for each metal by running suitable concentrations of their standard solutions, from which the concentrations of the elements were obtained by extrapolation. Average values of three replicates were taken for each determination. The absorbance of the blank was taken before the analysis of the samples.

\section{Risk assessment}

Risk assessment is a function of hazard and exposure and is defined as the process of estimating the probability of occurrence of any given probable magnitude of adverse health effects over a definite time period (Chotpantarat et al. 2014).

The health risk assessment of potentially toxic metal is usually based on the quantification of the risk level and is expressed in terms of a non-carcinogenic health hazard. The principal hazard toxicity factor evaluated is reference dose (RfD) (Tripathee et al. 2016). The estimation of the magnitude, frequency, and duration of human exposure to each potentially toxic metal in the environment is typically reported as average daily dose (ADD). Health risk assessment was evaluated for the metals in water via ingestion and dermal routes to the recipients as expressed in Eqs. 1 and 2. (USEPA 2004; Li and Zhang 2010),

$\mathrm{ADD}_{\text {ing }}=\frac{C \times \mathrm{IR} \times \mathrm{EF} \times \mathrm{ED}}{\mathrm{BW} \times \mathrm{AT}}$
$\mathrm{ADD}_{\text {derm }}=\frac{C \times \mathrm{SA} \times \mathrm{Kp} \times \mathrm{ET} \times \mathrm{EF} \times \mathrm{ED} \times \mathrm{CF}}{\mathrm{BW} \times \mathrm{AT}}$

where $\mathrm{ADD}_{\text {ing }}$ : average daily dose through ingestion of water $(\mathrm{g} / \mathrm{kg} / \mathrm{d})$; $\mathrm{ADD}_{\text {derm }}$ : average daily dose through dermal absorption $(\mathrm{g} / \mathrm{kg} / \mathrm{d}) ; C$ : concentration of metals in water $(\mathrm{g} / \mathrm{L})$; IR: water ingestion rate $(2.2 \mathrm{~L} / \mathrm{d})$; EF: exposure frequency ( $365 \mathrm{~d} / \mathrm{yr}$ ); ED: exposure duration (70 years); BW: average bodyweight $(70 \mathrm{~kg})$; AT: averaging time $\left(25,550\right.$ days); SA: exposed skin area $\left(18,000 \mathrm{~cm}^{2}\right)$; ET: exposure time $(0.58 \mathrm{~h} / \mathrm{d})$; CF: unit conversion factor $(0.001$ $\left.\mathrm{L} / \mathrm{cm}^{3}\right)$; and Kp: dermal permeability coefficient $(\mathrm{cm} / \mathrm{h})$, 0.001 for $\mathrm{Cd}, \mathrm{Fe}$ and $\mathrm{Pb}$ and 0.0006 for $\mathrm{Zn}$ (USEPA 2004; Liang et al. 2011; Iqbal and Shah 2013).

The potential for chronic non-carcinogenic risks of exposure to each metal was assessed by comparison of the calculated ADD for each exposure route with the oral/dermal reference dose (RfD). The non-carcinogen hazard was calculated as the hazard quotient (HQ), as given in Eq. (3) (Akoto et al. 2015; USEPA 2010).

$\mathrm{HQ}_{\text {ing/derm }}=\frac{\mathrm{ADD}_{\text {ing/derm }}}{\mathrm{RfD}_{\text {ing/derm }}}$

where $\mathrm{HQ}_{\text {ing/derm }}$ : hazard quotient via ingestion or dermal contact; and RfD oral/dermal reference dose $(\mu \mathrm{g} / \mathrm{kg}$-d) (USEPA 2010; Li and Zhang 2010).

For hazard characterization, if the value of hazard quotient (HQ) exceeds 1, then there is an unacceptable risk of adverse non-carcinogenic health effects, while if the HQ is less than 1 then it is at an acceptable level (USEPA 2010). The HQ is an estimation of the systemic toxicity potential posed by a single element within a single route of exposure. To evaluate the overall potential for non-carcinogenic effects posed by mixture of element, the individual HQs are combined to form the hazard index $(\mathrm{HI})$, when $\mathrm{HI}>1$ means an unacceptable risk of non-carcinogenic health effects, while $\mathrm{HI}<1$ means an acceptable level of risk (USEPA 2010; Li and Zhang 2010).

$\mathrm{HI}_{\text {ing/derm }}=\sum_{i=1}^{n} \mathrm{HQ}_{\mathrm{ing} / \mathrm{derm}}$

Carcinogenic risk (CR) was estimated as the incremental probability of an individual developing cancer over a lifetime as a result of exposure to a potential carcinogen; the following equation was used for computing the carcinogenic risk ( $\mathrm{Li}$ and Zhang 2010).

$\mathrm{CR}_{\text {ing }}=\frac{\mathrm{ADD}_{\text {ing }}}{\mathrm{SF}_{\text {ing }}}$ 
where $\mathrm{CR}_{\text {ing }}$ is carcinogenic risk via ingestion route; $\mathrm{SF}_{\text {ing }}$ is the carcinogenic slope factor, ingestion. The $\mathrm{SF}_{\text {ing }}$ values for $\mathrm{Cd}$ and $\mathrm{Pb}$ are 6.1E+03, and 8.5E+00, respectively, (USEPA 2010; Vieira et al. 2011; Yu et al. 2010). In general, a cancer risk value of $1.0 \mathrm{E}-06$ is the upper limit of acceptable cancer risk. If cancer risk exceeds $1.0 \mathrm{E}-06$, individuals will have increased risk of developing cancer due to lifetime exposure to the concerned toxicants (USEPA 2010).

\section{Results and discussion}

The physicochemical parameters obtained from analysis of the water samples collected from the hand-dug wells are presented in Table 1. The well water within the study area had $\mathrm{pH}$ values ranging from $7.32 \pm 0.07$ in well $\mathrm{A}_{6}$ to $7.50 \pm 0.09$ in Well $A_{2}$. Water in all the wells was slightly alkaline but had their $\mathrm{pH}$ within the WHO recommended range of 6.5-8.5 for drinking water (WHO 2010). At these $\mathrm{pHs}$, the efficiency of dissolving and leaching of toxic metal from the surface through the soil to groundwater is insignificant (Chotpantarat et al. 2014). Therefore, $\mathrm{pH}$ had no influence on the levels of metals in the groundwater.

EC values of the groundwater samples are presented in Table 1. EC gives an indication of the amount of total dissolved substitution in water (Yilmaz and Koc 2014). The EC values obtained ranges from $117 \pm 3.66$ to $421 \pm 2.83 \mu \mathrm{S} /$ $\mathrm{cm}$. The average electrical conductivity of the water sample recorded was $215 \pm 116 \mu \mathrm{S} / \mathrm{cm}$. Well $\mathrm{A}_{6}$ recorded the highest conductivity value and the lowest value was recorded by well $\mathrm{A}_{4}$. The average values of the E.C for all the wells were below the WHO recommended values that range from 1000 to $1500 \mu \mathrm{S} / \mathrm{cm}$. The highest mean concentration of the EC recorded in the shallow wells within the study area was below the WHO recommended limit of $1500 \mu \mathrm{S} / \mathrm{cm}$. The relatively low conductivity of the groundwater samples for the entire study area gives a picture of very little solute dissolution generally in the shallow groundwater (Oyem et al. 2014).

\section{Alkalinity}

WHO does not have any value as the acceptable limit for alkalinity in water for domestic use, because alkalinity does not pose any known health risk to humans. But the USGS states that concentrations above $300 \mathrm{mg} / \mathrm{L} \mathrm{HCO}_{3}$ will have some effect on the palatability of the drinking water. Well $\mathrm{A}_{1}$ recorded the highest concentration at $372 \pm 2.44 \mathrm{mg} / \mathrm{L}$ $\mathrm{HCO}_{3}$, and the lowest concentration of $220 \pm 0.25 \mathrm{mg} / \mathrm{L}$ $\mathrm{HCO}_{3}$ was recorded at well $\mathrm{A}_{3}$. Wells $\mathrm{A}_{1}$ and $\mathrm{A}_{6}$ had the alkalinity levels above the USGS limit.

\section{Total hardness}

Studies have shown that regular consumption of hard water can have a lowering effect on the rate of cardiovascular disease. However, there are some negative effects associated with the used of hard water. These include wastage of soap, staining of washed clothes and scaling of pipes and boilers (Afuye et al. 2015; Sengupta 2013). This study found that the total hardness of water from shallow groundwater wells in this area ranged from $206 \pm 4.09 \mathrm{mg} / \mathrm{L}$ in well $\mathrm{A}_{2}$ to $921 \pm 3.82 \mathrm{mg} / \mathrm{L}$ in well $\mathrm{A}_{6}$. WHO recommends total hardness levels in water to be $500 \mathrm{mg} / \mathrm{L}$. This implies that the average concentration of hardness of the sampling area is acceptable for human consumption. No health-based guideline value has been proposed for hardness; however, the degree of hardness in water may affect its acceptability to the consumer in terms of taste and scale deposition.

\section{Chloride}

High chloride levels in water may arise from sources such as runoff containing salts, the use of inorganic fertilizers, landfill leachates and septic tank effluents (Ugboaja 2004; Afuye et al. 2015). Although chloride in water seems not to pose any health hazard to humans, consumption of an excessive amount of it can lead to some health hazard even though the ion is known to be non-cumulative. High chloride levels may also render freshwater unsuitable for agricultural irrigation (Afuye et al. 2015). Concentration of $\mathrm{Cl}^{-}$in the water samples from the study area ranges from $95.36 \pm 2.11$ to $499.68 \pm 3.12 \mathrm{mg} / \mathrm{L}$. Well $\mathrm{A}_{6}$ recorded the highest $\mathrm{Cl}^{-}$concentration which is above the recommended WHO limit of $250 \mathrm{mg} / \mathrm{L}$. All the remaining wells recorded values below the WHO limit for drinking water with well $\mathrm{A}_{2}$ recording the lowest chloride concentration (Table 2) variation in $\mathrm{Cl}^{-}$concentrations among the wells was significant. This
Table 1 Physical properties of water from the shallow wells from Anloga

\begin{tabular}{llrllll}
\hline Parameters & \multicolumn{5}{l}{ Samples identity } \\
\cline { 2 - 7 } & $\mathrm{A}_{1}$ & \multicolumn{1}{c}{$\mathrm{A}_{2}$} & \multicolumn{1}{c}{$\mathrm{A}_{3}$} & \multicolumn{1}{c}{$\mathrm{A}_{4}$} & \multicolumn{1}{c}{$\mathrm{A}_{5}$} & $\mathrm{~A}_{6}$ \\
\hline $\mathrm{pH}$ & $7.43 \pm 1.02$ & $7.50 \pm 0.09$ & $7.36 \pm 0.09$ & $7.46 \pm 1.10$ & $7.45 \pm 1.04$ & $7.32 \pm 0.07$ \\
$\mathrm{EC}(\mu \mathrm{S} / \mathrm{cm})$ & $284 \pm 2.11$ & $140 \pm 6.04$ & $168 \pm 5.07$ & $117 \pm 3.66$ & $164 \pm 0.67$ & $421 \pm 2.83$ \\
Alkalinity $(\mathrm{mg} / \mathrm{L})$ & $372 \pm 2.44$ & $284 \pm 0.91$ & $220 \pm 0.25$ & $232 \pm 5.11$ & $268 \pm 3.68$ & $332 \pm 2.16$ \\
Hardness $(\mathrm{mg} / \mathrm{L})$ & $309 \pm 7.12$ & $206 \pm 4.09$ & $270 \pm 7.21$ & $191 \pm 5.33$ & $316 \pm 5.89$ & $921 \pm 3.82$ \\
\hline
\end{tabular}


Table 2 Mean levels of some chemical characteristics of the shallow well water samples from the Angola area

\begin{tabular}{|c|c|c|c|c|c|c|}
\hline \multirow[t]{2}{*}{ Parameters } & \multicolumn{6}{|c|}{ Samples identity } \\
\hline & $\mathrm{A}_{1}$ & $\mathrm{~A}_{2}$ & $\mathrm{~A}_{3}$ & $\mathrm{~A}_{4}$ & $\mathrm{~A}_{5}$ & $\mathrm{~A}_{6}$ \\
\hline Chloride & $125.13 \pm 0.11$ & $59.93 \pm 0.41$ & $119.89 \pm 6.21$ & $97.80 \pm 1.89$ & $95.36 \pm 2.11$ & $499.68 \pm 3.12$ \\
\hline Fluoride & $0.06 \pm 0.02$ & $0.28 \pm 0.01$ & $0.11 \pm 0.01$ & $0.13 \pm 0.16$ & $0.33 \pm 0.11$ & $0.31 \pm 0.11$ \\
\hline Nitrate & $169.95 \pm 2.19$ & $99.21 \pm 2.88$ & $98.11 \pm 6.03$ & $30.78 \pm 1.33$ & $119.31 \pm 4.26$ & $17.20 \pm 1.76$ \\
\hline Sulfate & $97.52 \pm 1.92$ & $47.14 \pm 2.19$ & $99.93 \pm 2.87$ & $68.64 \pm 1.29$ & $62.11 \pm 1.96$ & $856.78 \pm 4.11$ \\
\hline Calcium & $80.00 \pm 4.53$ & $72.00 \pm 1.23$ & $76.80 \pm 2.77$ & $148.80 \pm 3.19$ & $72.00 \pm 0.18$ & $308.80 \pm 2.11$ \\
\hline Magnesium & $30.85 \pm 2.20$ & $28.24 \pm 2.71$ & $29.87 \pm 0.11$ & $58.79 \pm 1.95$ & $28.81 \pm 1.52$ & $118.72 \pm 2.11$ \\
\hline Sodium & $39.50 \pm 0.15$ & $22.40 \pm 0.55$ & $38.70 \pm 0.32$ & $30.90 \pm 0.22$ & $26.90 \pm 0.12$ & $92.30 \pm 2.12$ \\
\hline Potassium & $19.10 \pm 0.06$ & $9.40 \pm 0.42$ & $12.30 \pm 0.94$ & $9.20 \pm 0.01$ & $22.90 \pm 0.96$ & $29.60 \pm 0.41$ \\
\hline
\end{tabular}

is an indication of possible anthropogenic influence in the $\mathrm{Cl}^{-}$concentration in the wells.

\section{Fluoride}

Health studies have shown that the addition of $\mathrm{F}^{-}$to water supplies in levels above $0.6 \mathrm{mg} / \mathrm{L}$ of $\mathrm{F}^{-}$could lead to a reduction in tooth decay especially in growing children. On the other hand, consumption of water with $\mathrm{F}^{-}$concentration above $1.5 \mathrm{mg} / \mathrm{L}$ leads to dental fluorosis and in extreme cases skeletal fluorosis (Kumar and Puri 2012). Concentrations of fluoride recorded vary from $0.06 \pm 0.02$ to $0.33 \pm 0.11 \mathrm{mg} / \mathrm{L}$. Well $\mathrm{A}_{5}$ recorded the highest fluoride concentration and well $\mathrm{A}_{1}$ recorded the lowest. Fluoride levels in all the samples were below WHO recommended concentration of $1.5 \mathrm{mg} / \mathrm{L}$ (Kumar and Puri 2012). Thus, the water from the wells does not pose any $\mathrm{F}^{-}$-related health issues on consumers. There was no significant variation in $\mathrm{F}^{-}$concentrations within the sampled wells.

\section{Sulfate}

Sulfides of metals that are present mainly in sedimentary rocks can be oxidized to sulfate which can leach and contaminate shallow groundwater. Excess sulfate in drinking water has a laxative effect, especially in combination with other metals such as $\mathrm{Mn}$ and $\mathrm{Na}$ (Chindo et al. 2013). The use of water for domestic purposes is therefore limited by high sulfate concentrations; hence, a limit of $500 \mathrm{mg} / \mathrm{L}$ has been set by the WHO for drinking water. The sulfate levels in water from the shallow wells ranged within the study area ranged from $47.14 \pm 2.19 \mathrm{mg} / \mathrm{L}$ in well $\mathrm{A}_{2}$ to $856.78 \pm 4.11 \mathrm{mg} / \mathrm{L}$ in well $\mathrm{A}_{6}$. Sulfate content of all the well water was below the WHO limit set for drinking water except that of well $\mathrm{A}_{6}$.

\section{Nitrates}

Contamination of $\mathrm{NO}_{3}{ }^{-}$in groundwater may result from runoff of inorganic fertilizers from farmlands and soluble $\mathrm{NO}_{3}{ }^{-}$compounds from nitrogenous waste products in human and animal excreta that may leach into the wells (Chindo et al. 2013). Nitrate is therefore one of the most common groundwater contaminants in rural or farming areas. High level of $\mathrm{NO}_{3}{ }^{-}$in drinking water can cause methemoglobinemia in infants. Nitrate can also be converted to nitrite after ingestion which can react $\backslash$ with organic compounds to produce N-nitroso compounds in the stomach. Many of these $\mathrm{N}$-nitroso compounds are carcinogenic to humans (Xu et al. 2015). Concentrations of $\mathrm{NO}_{3}{ }^{-}$in the water samples ranged from $17.20 \pm 1.76$ in well $\mathrm{A}_{6}$ to $169.95 \pm 2.19 \mathrm{mg} / \mathrm{L} \mathrm{NO}_{3}{ }^{-}$in well $\mathrm{A}_{1}$. Wells $1_{\mathrm{A}}, 2_{\mathrm{A}}, 3_{\mathrm{A}}$ and $5_{\mathrm{A}}$ had their mean $\mathrm{NO}_{3}{ }^{-}$concentrations above the WHO recommended value of $50 \mathrm{mg} / \mathrm{L}$ for drinking water. The high concentrations of $\mathrm{NO}_{3}{ }^{-}$may be of high potential health risks to human especially infants who use this water from these wells for domestic purposes including drinking. Even though no significant variations were observed in the $\mathrm{NO}_{3}{ }^{-}$concentrations within the water samples from the individual wells, significant variation in $\mathrm{NO}_{3}^{-}$levels was observed among the different wells.

\section{Calcium}

Calcium is one of the essential elements that are beneficial to human health, though is one of the ion that contribute to water hardness. Waters which are rich in calcium possess a high degree of hardness and are very palatable. Adequate intake of calcium helps in strengthening bones and teeth (Sengupta 2013). There is some evidence indicating that the incidence of heart disease is reduced in areas served water with a high degree of hardness. Concentrations of calcium determined in water from the shallow wells within the sample area range from $72.00 \pm 1.23$ to $308.80 \pm 2.11 \mathrm{mg} / \mathrm{L}$. Well $\mathrm{A}_{6}$ recorded the highest value, while well $\mathrm{A}_{2}$ recorded the lowest concentration as presented in Table 2 .

Concentrations of magnesium in the water samples ranged from $28.24 \pm 2.71$ to $118.72 \pm 2.11 \mathrm{mg} / \mathrm{L}$, and well $\mathrm{A}_{6}$ recorded the highest concentration and well $\mathrm{A}_{2}$ recorded the lowest. Generally, the concentrations of $\mathrm{Na}$ and $\mathrm{K}$ in all the water from the wells were low. Levels of these metals in

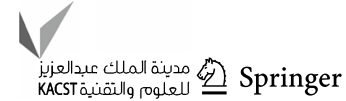


all the wells were below their recommended values by the WHO for drinking water. Statistical analysis showed that there were no significant variations in the concentrations of $\mathrm{Na}$ and $\mathrm{K}$ within the wells as well as among the different wells considered for this work.

Some heavy metals are useful to the human system in very small quantities. Iron, for example, is made a part of some multivitamin drugs and products. Although iron is a very important dietary requirement in the human system, too much iron in drinking water could cause gastrointestinal upset, nausea, vomiting and constipation in severe cases, iron toxicity could lead to organ damage, coma or even death (Grazuleviciene et al. 2009). Concentrations of Fe recorded in the water samples ranged from BDL to $0.46 \mathrm{mg} / \mathrm{L}$. Two of the wells $\left(\mathrm{A}_{2}\right.$ and $\left.\mathrm{A}_{4}\right)$ had their Fe concentrations above the WHO recommended. The mean Fe concentrations recorded in the other wells were below the WHO recommended value of $0.3 \mathrm{mg} / \mathrm{L}$.

Zinc is also an essential micronutrient in human beings (Patil and Ahmad 2011). But at very high concentrations, it may cause some toxic effect. Zinc concentrations recorded in the water samples ranged from BDL to $0.047 \pm 0.01 \mathrm{mg} / \mathrm{L}$ (Table 2). The mean concentration of $\mathrm{Zn}$ in all the samples was below the WHO recommended value of $3.0 \mathrm{mg} / \mathrm{L}$.

Long-term exposure to even low concentrations of $\mathrm{Cd}$ can cause adverse health effects on the kidneys and lungs (Dutta et al. 2015). In this study, Cd concentration ranges from BDL in well $\mathrm{A}_{4}$ to $0.04 \mathrm{mg} / \mathrm{L}$ in well $\mathrm{A}_{2}$. Cadmium levels in all the water samples from the wells were high than the WHO recommended value of $0.005 \mathrm{mg} / \mathrm{L}$ except that of well $\mathrm{A}_{4}$. The high levels of $\mathrm{Cd}$ in the water samples may be due to anthropogenic activities that include fertilizer use. This is because the main activity in the study area is agriculture. The use of fertilizers is known to increase $\mathrm{Cd}$ in the environment (Wu et al. 2010).

Lead exposure is associated with multiple health effects on different organ systems at both elevated and at distinctive levels (Health Canada 2013; Brown and Margolis 2012). At elevated levels, lead can lead to seizures and eventually death. At low levels of lead exposure, there is a large body of evidence to demonstrate that lead is associated with a number of different neurological and developmental outcomes
(Health Canada 2013; NTP 2012; US EPA 2013). In this study, well A6 recorded mean $\mathrm{Pb}$ level that was higher than the WHO recommended value of $0.01 \mathrm{mg} / \mathrm{L}$ Lead (Table 3).

Ingestion of water containing significant amount of metal is toxic and poses risks to human health. Concentration of the heavy metals that were considered in this work $(\mathrm{Cd}, \mathrm{Pb}$, $\mathrm{Fe}$ and $\mathrm{Zn}$ ) in the selected wells shows that $\mathrm{Cd}$ and $\mathrm{Pd}$ toxicities are present in some of the well samples since their concentrations in some of the wells were high than the WHO accepted limit for drinking. Based on the metal metals levels in the water samples from the wells, non-carcinogenic hazard through ingestion and dermal exposures were assessed and the results presented in Table 4. In this study, the $\mathrm{HQ}_{\text {ing }}$ ranged from $1.05 \mathrm{E}-03$ for $\mathrm{Zn}$ in well $\mathrm{A}_{6}$ to 2.52 for $\mathrm{Cd}$ in well $\mathrm{A}_{2}$. The $\mathrm{HQ}_{\text {ing }}$ values for $\mathrm{Cd}$ in wells 2,3 and 5 were observed to be higher than the safety limit of 1 , whereas that recorded for $\mathrm{Fe}, \mathrm{Zn}$ and $\mathrm{Pb}$ in all the well water samples were far below the safety limit, this demonstrated that these metals could not pose adverse health effects to the recipients via ingestion of contaminated water. Again the estimated HI values due to ingestion of water from the wells selected in this study ranged from $2.45 \mathrm{E}-01$ in well $4-2.54$ in well 2 Table 4. The HI in few of the wells were less than 1, indicating small to no hazard to the local population; however, high non-carcinogenic hazards were recorded in well 2, 3 and 5 indicating a potential hazard to the health of the local residents.

On the other hand, the $\mathrm{HQ}_{\text {derm }}$ values of all the metals detected in the water samples were found to be lower than one (1), indicating that there was no health risk associated with water samples via dermal absorption or skin exposure to the inhabitants (Table 5). $\mathrm{Zn}$ in well $\mathrm{A}_{1}$ recorded the least $\mathrm{HQ}_{\text {derm, }}$, while $\mathrm{Cd}$ in well $\mathrm{A}_{5}$ recorded the highest. However, the estimated levels of $\mathrm{HI}_{\text {derm }}$ were also less than the safe limit of 1, indicating that there were no cumulative potential adverse health risks in water samples via dermal absorption. Well $\mathrm{A}_{3}$ and $\mathrm{A}_{5}$ recorded the highest cumulative potential for non-carcinogenic health risks due to dermal exposure as presented in Table 5.

Heavy metal such as $\mathrm{Cd}$ and $\mathrm{Pb}$ that were considered in this work is known to have the potential to produce carcinogenic risk when one is exposed (De Miguel et al. 2007;
Table 3 Mean concentrations $(\mathrm{mg} / \mathrm{L})$ of heavy metals in the well water samples

\begin{tabular}{lllll}
\hline Sample point & $\mathrm{Pb}$ & $\mathrm{Cd}$ & $\mathrm{Fe}$ & $\mathrm{Zn}$ \\
\hline Well $\mathrm{A}_{1}$ & $0.01 \pm 0.00$ & $0.01 \pm 0.00$ & $0.22 \pm 0.02$ & $0.047 \pm 0.01$ \\
Well A $_{2}$ & $\mathrm{BDL}$ & $0.04 \pm 0.012$ & $0.35 \pm 0.01$ & $\mathrm{BDL}$ \\
Well A $_{3}$ & $\mathrm{BDL}$ & $0.03 \pm 0.01$ & $0.03 \pm 0.02$ & $0.033 \pm 0.01$ \\
Well A $_{4}$ & $0.01 \pm 0.00$ & $\mathrm{BDL}$ & $0.463 \pm 0.006$ & $\mathrm{BDL}$ \\
Well A $_{5}$ & $\mathrm{BDL}$ & $0.02 \pm 0.01$ & $\mathrm{BDL}$ & $\mathrm{BDL}$ \\
Well A $_{6}$ & $0.012 \pm 0.00$ & $0.010 \pm 0.00$ & $0.20 \pm 0.01$ & $0.01 \pm 0.00$ \\
WHO limit & 0.01 & 0.005 & 2.0 & 3.0 \\
\hline
\end{tabular}


Table 4 Non-carcinogenic health risk for heavy metals in the well water samples from the Anloga community through oral exposure
Table 5 Non-carcinogenic health risk for heavy metals in the well water samples from the Anloga community through dermal exposure

\begin{tabular}{|c|c|c|c|c|c|c|}
\hline $\mathrm{ADD}$ & ion) & $\mathrm{Pb}$ & $\mathrm{Cd}$ & $\mathrm{Fe}$ & $\mathrm{Zn}$ & $\mathrm{HI}=\sum^{n} \mathrm{HO}$ \\
\hline Well 1 & ADD & $3.14 \mathrm{E}-01$ & $3.14 \mathrm{E}-01$ & 6.91 & 1.45 & \\
\hline & HQ & $2.24 \mathrm{E}-01$ & $6.28 \mathrm{E}-01$ & $9.87 \mathrm{E}-03$ & $4.93 \mathrm{E}-03$ & $8.67 \mathrm{E}-01$ \\
\hline Well 2 & ADD & - & 1.26 & $1.10 \mathrm{E}+1$ & - & \\
\hline & HQ & - & 2.52 & $1.57 \mathrm{E}-02$ & - & 2.54 \\
\hline Well 3 & ADD & - & $9.43 \mathrm{E}-01$ & $9.43 \mathrm{E}-01$ & 1.04 & \\
\hline & HQ & - & 1.89 & $1.35 \mathrm{E}-03$ & $3.47 \mathrm{E}-03$ & 1.89 \\
\hline Well 4 & $\mathrm{ADD}$ & $3.14 \mathrm{E}-01$ & - & $1.45 \mathrm{E}+1$ & - & \\
\hline & HQ & $2.24 \mathrm{E}-01$ & - & $2.07 \mathrm{E}-02$ & - & $2.45 \mathrm{E}-01$ \\
\hline Well 5 & ADD & - & $6.24 \mathrm{E}-01$ & - & - & \\
\hline & HQ & & 1.26 & - & - & 1.26 \\
\hline Well 6 & ADD & $3.14 \mathrm{E}-01$ & $3.14 \mathrm{E}-01$ & 6.29 & $3.14 \mathrm{E}-01$ & \\
\hline & HQ & $2.24 \mathrm{E}-01$ & $6.28 \mathrm{E}-01$ & $8.99 \mathrm{E}-03$ & $1.05 \mathrm{E}-03$ & $8.62 \mathrm{E}-01$ \\
\hline RfD & & 1.4 & 0.5 & 700 & 300 & \\
\hline ADD ( & & $\mathrm{Pb}$ & $\mathrm{Cd}$ & $\mathrm{Fe}$ & $\mathrm{Zn}$ & $\mathrm{HI}=\sum_{i=1}^{n} \mathrm{HQ}$ \\
\hline Well 1 & ADD & $1.49 \mathrm{E}-03$ & $1.49 \mathrm{E}-03$ & $3.28 \mathrm{E}-02$ & $4.21 \mathrm{E}-03$ & \\
\hline & HQ & $3.55 \mathrm{E}-03$ & $5.96 \mathrm{E}-02$ & $2.34 \mathrm{E}-04$ & $7.02 \mathrm{E}-05$ & $6.35 \mathrm{E}-02$ \\
\hline Well 2 & ADD & - & $5.97 \mathrm{E}-03$ & $5.22 \mathrm{E}-02$ & - & \\
\hline & HQ & - & $2.39 \mathrm{E}-01$ & $3.73 \mathrm{E}-04$ & - & $2.39 \mathrm{E}-01$ \\
\hline Well 3 & ADD & - & $4.47 \mathrm{E}-03$ & $4.47 \mathrm{E}-03$ & $2.95 \mathrm{E}-03$ & \\
\hline & HQ & - & $1.79 \mathrm{E}-01$ & $3.19 \mathrm{E}-05$ & $4.92 \mathrm{E}-05$ & $1.79 \mathrm{E}-01$ \\
\hline Well 4 & ADD & $1.49 \mathrm{E}-03$ & & $6.86 \mathrm{E}-02$ & & \\
\hline & HQ & $3.55 \mathrm{E}-03$ & - & $4.90 \mathrm{E}-04$ & - & $4.04 \mathrm{E}-03$ \\
\hline Well 5 & ADD & - & $2.98 \mathrm{E}-03$ & - & - & \\
\hline & HQ & - & $1.19 \mathrm{E}-01$ & - & - & $1.19 \mathrm{E}-01$ \\
\hline Well 6 & ADD & $1.49 \mathrm{E}-03$ & $1.49 \mathrm{E}-03$ & $2.98 \mathrm{E}-02$ & $8.95 \mathrm{E}-04$ & \\
\hline & HQ & $3.55 \mathrm{E}-03$ & $5.96 \mathrm{E}-02$ & $2.13 \mathrm{E}-04$ & $1.49 \mathrm{E}-05$ & $6.34 \mathrm{E}-02$ \\
\hline RfD & & 0.42 & 0.025 & 140 & 60 & \\
\hline
\end{tabular}

Tchounwou et al. 2014). The probable carcinogenic risks posed by these metals through ingestion for the residents within the study area were estimated using Eq. 5. The results showed that $\mathrm{CR}_{\text {ing }}$ for $\mathrm{Pb}$ in the water samples was $3.69 \mathrm{E}-06$ in all the well water samples where $\mathrm{Pb}$ was detected. The risk of developing cancer from $\mathrm{Pb}$ as a result of consuming water from wells $\mathrm{A}_{1}, \mathrm{~A}_{2}$ and $\mathrm{A}_{5}$ showed no significant differences $(p>0.05)$. In general, EPA considers excess cancer risks that are below about 1 chance in 1,000,000 (1.0E-06) to be so small as to be negligible. In this study, there is a possibility of 3-4 persons in every $1,000,000$ developing cancer as results of lifetime exposure to $\mathrm{Pb}$ in water from the wells. Cancer risk computed for $\mathrm{Cd}$ ranged from $1.82 \mathrm{E}-02$ in a well $\mathrm{A}_{5}$ to $9.09 \mathrm{E}-02$ in well $\mathrm{A}_{1}$ and $\mathrm{A}_{6}$. These risk values indicate that consumption of water from these wells would result in an excess of 2-9 cancer cases per 100 people. Cadmium emissions have increased dramatically in recent years, reason being that cadmium-containing products are seldom recycled, but ends up at refuse dump together with household waste. Recent data indicate that adverse health effects of cadmium exposure may occur at lower exposure levels than previously anticipated resulting in lung cancer, kidney damage and also bone effect and fractures. Therefore, measures should be taken to reduce $\mathrm{Cd}$ exposure in order to minimize the risk of adverse health effects (Järup 2003) (Table 6).

\section{Conclusion}

Physicochemical parameters of the water samples were within permissible limits except well $\mathrm{A}_{1}$ where the water was significantly contaminated with nitrate and chloride. Concentrations of $\mathrm{Cd}$ and $\mathrm{Pb}$ were higher than the maximum 
Table 6 Carcinogenic health risk for heavy metals in the well water samples from the Anloga community through oral exposure

\begin{tabular}{lll}
\hline Well & $\mathrm{Pb}$ & $\mathrm{Cd}$ \\
\hline Well $_{1}$ & $3.69 \mathrm{E}-06$ & $9.09 \mathrm{E}-02$ \\
Well $_{2}$ & - & $3.64 \mathrm{E}-02$ \\
Well $_{3}$ & $3.69 \mathrm{E}-06$ & $2.73 \mathrm{E}-02$ \\
Well $_{4}-$ & - \\
Well $_{5}-$ & $1.82 \mathrm{E}-02$ \\
Well $_{6}$ & $3.69 \mathrm{E}-06$ & $9.09 \mathrm{E}-02$ \\
\hline
\end{tabular}

Akoto O, Gavor S, Appah MK, Apau J (2015) Estimation of human health risk associated with the consumption of pesticide-contaminated vegetables from Kumasi, Ghana. Environ Monit Assess 187:244. https://doi.org/10.1007/s10661-015-4471-0

Anawara HM, Akaib J, Mostofac KMG, Safiullahd S, Tareqd SM (2002) Arsenic poisoning in groundwater health risk and geochemical sources in Bangladesh. Environ Int 27:597-604

Asante KA, Agusa T, Subramanian A, Ansa-Asare OD, Biney CA, Tanabe $S$ (2007) Contamination status of arsenic and other trace elements in drinking water and residents from Tarkwa, a historic mining township in Ghana. Chemosphere 66:1513-1522

Boswinkel JA (2000) Information Note, International Groundwater Resources Assessment Centre (IGRAC), Netherlands Institute of Applied Geoscience, Netherlands. In: UNEP (2002) Vital water graphics-an overview of the state of the world's fresh and marine waters. UNEP, Nairobi, Kenya

Brown MJ, Margolis S (2012) Lead in drinking water and human blood lead levels in the United States. Centres for Disease Control and Prevention. Morbidity and Mortality Weekly Report. Supplement 61

Chindo YY, Karu E, Ziyok I, Amanki ED (2013) Physicochemical analysis of ground water of selected areas of Dass and Ganjuwa Local Government Areas, Bauchi State, Nigeria. World J Anal Chem 1(4):73-79

Chotpantarat S, Wongsasuluk P, Siriwong W, Borjan M, Robson R (2014) Non-Carcinogenic Hazard Maps of heavy metals contamination in shallow groundwater for adults and aging population at an agricultural area in Northeastern Thailand. Hum Ecol Risk Assess 20:689-703

De Miguel E, Iribarren I, Chacón E, Ordoñez A, Charlesworth S (2007) Risk-based evaluation of the exposure of children to trace elements in playgrounds in Madrid (Spain). Chemosphere 66(3):505-513

Dutta B, Sarma SR, Deka P (2015) Lead nitrate toxicity on haematological changes in a live fish species Channa punctatus (Bloch). J Int J Fish Aquat Stud 3(2):196-198

Grazuleviciene R, Nadisauskiene R, Buinauskiene J, Grazulevicius T (2009) Effects of elevated levels of manganese and iron in drinking water on birth outcomes. Polish J Environ Stud 18(5):819-825

Guo JX, Hu L, Tanabe K, Miyatalre M, Chen Y (2007) Chronic arsenic poisoning in drinking water in Inner Mongolia and its associated health effects. J Environ Sci Health A 42(12):1853

Gyau-Boakye P, Dapaa-Siakwan (2000) Groundwater as sources of rural water supply in Ghana. J Appl Sci Technol 5(1 \& 2):77-86

Health Canada (2013) Final human health state of the science report on lead. Available at http://www.hcsc.gc.ca/ewhsemt/alt_forma ts/pdf/pubs/contaminants/dhhssrlrpecscepsh/dhhssrl-rpecscepsh -eng.pdf. Assessed 20th Feb 2017

Helstrup T (2006) Environmental isotopic and hydrochemical characteristics of groundwater from the cretaceous-eocene limestone aquifer in the Keta Basin, Ghana, and the Coastal Sedimentary Basin of Togo Ph.D. Thesis, Geological Institute Faculty of Science University of Copenhagen

Iqbal J, Shah MH (2013) Health risk assessment of metals in surface water from freshwater source lakes, Pakistan. Hum Ecol Risk Asses 19:1530-1543

ISARM (International Shared Aquifer Resources Management) (2009) Transboundary Aquifers of the World (2009 update). Presented during a special meeting at World Water Forum 5. Utrecht, The Netherlands, ISARM. http://www.isarm.net/publications/319\#9. Assessed 12th Dec 2017

Järup L (2003) Hazards of heavy metal contamination. Br Med Bull 68:167-182. https://doi.org/10.1093/bmb/ldg032

Johnson FO, Atchison WD (2009) The role of environmental mercury, lead and pesticide exposure in development of amyotrophic lateral sclerosis. Neurotoxicology 30(5):761-765 
Kortatsi BK (1994) Groundwater utilization in Ghana. Future groundwater resources at risk (proceedings of the Helsinki conference). IAHS Publ. no. 222

Kumar M, Puri A (2012) A review of permissible limits of drinking water. Indian J Occup Environ Med 16(1):40-44

Lapworth DJ, Baran N, Stuart ME, Ward RS (2012) Emerging organic contaminants in groundwater: a review of sources, fate and occurrence. Environ Pollut 163:287-303

Li S, Zhang Q (2010) Risk assessment and seasonal variations of dissolved trace elements and heavy metals in the Upper Han River, China. J Hazard Mater 181:1051-1058

Liang F, Yang S, Sun C (2011) Primary health risk analysis of metals in surface water of Taihu Lake, China. Bull Environ Contam Toxicol 87:404-408

Marcovecchio JE, Botte SE, Freije RH (2007) Heavy metals, major metals, trace elements. In: Nollet LM (ed) Handbook of water analysis, 2nd edn. CRC Press, London, pp 275-311

Mishra KP (2009) Lead exposure and its impact on immune system: a review. Toxicol In Vitro 23(6):969-972

NTP (2012) NTP monograph. Health effects of low levels of lead. National Toxicology Program. US Department of Health and Human Services. June 13, 2012. Available at http://ntp.niehs.nih. gov/pubhealth/hat/noms/lead/index.html. Assessed 5th July 2016

Oyem HH, Oyem IM, Ezeweali D (2014) Temperature, pH, electrical conductivity, total dissolved solids and chemical oxygen demand of groundwater in Boji-Boji Agbor/Owa Area and immediate suburbs. Res J Environ Sci 8(8):444-450

Patil G, Ahmad I (2011) Heavy metals contamination assessment of Kanhargaon dam water near Chhindwara city. Acta Chim Pharm Indica 1(1):7-9

Ponce VM (2006) Groundwater utilization and sustainability. http:// groundwater.sdsu.edu. Assessed 20th Feb 2017

Prasanth SV, Magesh NS, Jitheshlal KV, Chandrasekar N, Gangadhar K (2012) Evaluation of groundwater quality and its suitability for drinking and agricultural use in the coastal stretch of Alappuzha District, Kerala, India. Appl Water Sci 2(3):165-175

Puri S, Aureli A (eds) (2009) Atlas of transboundary aquifers-Global maps, regional cooperation and local inventories. UNESCO-IHP ISARM Programme, UNESCO, Paris. [CD only.] http://www. isarm.org/publications/322. Assessed 2nd Oct 2016

Sengupta P (2013) Potential health impacts of hard water. Int J Prev Med 4(8):866-875

Shankar S, Shanker U, Shikha A (2014) Arsenic contamination of groundwater: a review of sources, prevalence, health risks, and strategies for mitigation. Sci World J. https://doi. org $/ 10.1155 / 2014 / 30452$

Tchounwou PB, Yedjou CG, Patlolla AK, Sutton DJ (2014) Heavy metals toxicity and the environment. Mol Clin Env Toxicol 101:133-164
Tripathee L, Kang S, Sharma CM, Rupakheti D, Paudyal R, Huang J, Sillanpää M (2016) Preliminary health risk assessment of potentially toxic metals in surface water of the Himalayan Rivers, Nepal. Bull Environ Contam Toxicol 97(6):855-862

Ugboaja AN (2004) Groundwater pollution near shallow waste dumps in southern Calabar, southeastern Nigeria. Glob J Geol Sci 2(2):199-206

UNEP (2003) Assessment of pollution status and vulnerability of water supply aquifers of Keta, Ghana, Activity Report- 2003

US EPA (2013) Integrated science assessment for lead. National Center for Environmental Assessment RTP Division Office of Research and Development U.S. Environmental Protection Agency, Research Triangle Park, NC. Available at:http://cfpub.epa.gov/ ncea/isa/recordisplay.cfm?deid=255721\#Download. Assessed 14th July 2016

USEPA (2004) Risk assessment guidance for superfund, vol 1, human health evaluation manual. Part E (supplemental guidance for dermal risk assessment), EPA/540/R/99/005. Office of Superfund Remediation and Technology Innovation, Washington, DC, USA

USEPA (2010) Risk assessment guidance for superfund, vol 1, human health evaluation manual, development of risk-based preliminary remediation goals (Part B). Washington, DC, USA

Vieira C, Morais S, Ramos S et al (2011) Mercury, cadmium, lead and arsenic levels in three pelagic fish species from the Atlantic Ocean: intra-and inter-specific variability and human health risks for consumption. Food Chem Toxicol 49:923-932

WHO (2010) Guideline for drinking water quality, 3rd edn. World Health Organization, Geneva

Wu S, Xia X, Lin C et al (2010) Levels of arsenic and heavy metals in the rural soils of Beijing and their changes over the last two decades (1985-2008). J Hazard Mater 179:860-868

Xu L, Qu Y. H, Chu XD, Wang R, Nelson HH, Gao YT, et al (2015) Urinary levels of $\mathrm{N}$-nitroso compounds in relation to risk of gastric cancer: findings from the Shanghai Cohort $S$

Yilmaz E, Koc C (2014) Physically and chemically evaluation for the water quality criteria in a farm on Akcay. J Water Resour Prot 6:63-67

Yu FC, Fang GH, Ru XW (2010) Eutrophication, health risk assessment and spatial analysis of water quality in Gucheng Lake, China. Environ Earth Sci 59:1741-1748

Zaporozec A (1981) Ground-water pollution and its sources. Geo J $5(5): 457-471$

Publisher's Note Springer Nature remains neutral with regard to jurisdictional claims in published maps and institutional affiliations. 